\title{
The Evaluation of Dipeptidyl Peptidase (DPP)-IV, $\alpha$-Glucosidase and Angiotensin Converting Enzyme (ACE) Inhibitory Activities of Whey Proteins Hydrolyzed with Serine Protease Isolated from Asian Pumpkin (Cucurbita ficifolia)
}

\author{
Babij Konrad - Dąbrowska Anna - Szołtysik Marek • \\ Pokora Marta · Zambrowicz Aleksandra • \\ Chrzanowska Józefa
}

Accepted: 17 May 2014/ Published online: 1 June 2014

(C) The Author(s) 2014. This article is published with open access at Springerlink.com

\begin{abstract}
In the present study, whey protein concentrate (WPC-80) and $\beta$-lactoglobulin were hydrolyzed with a noncommercial serine protease isolated from Asian pumpkin (Cucurbita ficifolia). Hydrolysates were further fractionated by ultrafiltration using membranes with cutoffs equal 3 and $10 \mathrm{kDa}$. Peptide fractions of molecular weight lower than 3 and 3-10 $\mathrm{kDa}$ were further subjected to the RP-HPLC. Separated preparations were investigated for their potential as the natural inhibitors of dipeptidyl peptidase (DPP-IV), $\alpha$-glucosidase and angiotensin converting enzyme (ACE). WPC-80 hydrolysate showed higher inhibitory activities against the three tested enzymes than $\beta$-lactoglobulin hydrolysate. Especially high biological activities were exhibited by peptide fractions of molecular weight lower than $3 \mathrm{kDa}$, with ACE IC50 $<0.64 \mathrm{mg} / \mathrm{mL}$ and DPP-IV IC50 $<0.55 \mathrm{mg} / \mathrm{mL}$. This study suggests that peptides generated from whey proteins may support postprandial glycemia regulation and blood pressure maintenance, and could be used as functional food ingredients in the diet of patients with type 2 diabetes.
\end{abstract}

Keywords Asian pumpkin - Serine protease - Bioactive peptides · DPP-IV inhibitors · ACE inhibitors · $\alpha$-Glucosidase inhibitors

B. Konrad $(\bowtie) \cdot$ D. Anna $\cdot$ S. Marek · P. Marta .

Z. Aleksandra $\cdot$ C. Józefa

Department of Animal Products Technology and Quality

Management, Wrocław University of Enviromental and Life

Sciences, ul. Chełmońskiego 37/41, 51-630 Wrocław, Poland

e-mail: konrad.babij@gmail.com

D. Anna

e-mail: anna.dabrowska@up.wroc.pl

\section{Introduction}

Diabetes mellitus is recognized as a major health problem affecting millions of people (Go et al. 2013). This endocrine disorder, characterized by hyperglycemia, is associated with disturbances of carbohydrate, fat and protein metabolism resulting from altered insulin sensitivity and impaired insulin secretion (Schmidt and Hickey 2009). The contemporary therapeutic approach to diabetes is to decrease postprandial hyperglycemia, as strict glycemic control reduces the microvascular complications (Holman et al. 2008).

A recently introduced family of anti-diabetic drugs is based on the inhibition of dipeptidyl peptidase-IV (DPPIV) and $\alpha$-glucosidase (Deacon 2011). The former, DPP-IV (E.C. 3.4.14.5), has post-proline dipeptidyl aminopeptidase activity, with the specificity for removing X-Pro or X-Ala dipeptides from the $\mathrm{N}$-terminus of polypeptides and proteins (Blanco et al. 1998; Hildebrandt et al. 2000). The endogenous physiological substrates of DPP-IV, two incretin hormones, glucagon-like peptide 1 (GLP-1) and glucose-dependent insulinotropic polypeptide (GIP) enhance glucose-induced insulin secretion during a meal. Actually, most of the secreted insulin is a result of the incretin response, mainly the combined action of GIP and GLP-1. However, both GIP and GLP-1, have a short halflife of 1-2 min, resulting from the cleaving activity of the enzyme (Psallas and Manes 2012). Therefore, the inhibition of the DPP-IV activity is seen as a promising treatment method in type 2 diabetes (Deacon 2011).

Another therapeutic approach in the management of postprandial hyperglycemia is based on the inhibition of $\alpha$-glucosidase. The membrane-bound $\alpha$-glucosidase (EC 3.2.1.20), present in the epithelial mucosa of the small intestine, cleaves glycosidic bonds in complex 
carbohydrate to release absorbable monosaccharides. The inhibition of $\alpha$-glucosidase disables the release of free glucose from complex carbohydrates, thus decreasing postprandial blood glucose levels (Jaiswal et al. 2012).

Insulin resistance is often accompanied by hypertension (Psallas and Manes 2012; Buttar et al. 2005) which, together with a high plasma glucose level, is responsible for the long-term complications of diabetes, such as microvascular defects. As hypertension occurs when the angiotensin converting enzyme (ACE, EC 3.4.15.1) catalyzes the conversion of angiotensin I into angiotensin II. ACE inhibitors are commonly prescribed to diabetic patients, also to decrease the risk of other complications, including cancer, peptic ulcer and diabetic retinopathy (Skeggs et al. 1956; Ramos-Nino et al. 2008). However, although ACE inhibitors such as captopril, enalapril and lisinopril are commonly used in the treatment of patients with hypertension, heart failure or diabetic nephropathies, they have significant undesirable side effects and safe alternatives are needed (Song and White 2002; Ionescu et al. 2002).

Various reports suggest that dietary proteins could be natural precursors of the inhibitors of dipeptidyl peptidase (DPP)-IV, $\alpha$-glucosidase and ACE (Huang et al. 2012; Lacroix and Li-Chan 2013, Silveira et al. 2013; Yu et al. 2011; Zambrowicz et al. 2013). Specific fragments of bioactive peptides have a beneficial impact on body functions, most notably on the nervous, immune, cardiovascular and digestive systems (Kitts and Weiler 2003; Haque and Chand 2008). The bioactive sequence in peptides may vary from 2 to 20 amino acid residues, and many peptides are known to have multi-functional properties (Haque and Chand 2008).

Dietary proteins may be an excellent source of biologically active peptides. These peptides, inactive within the sequence of the native protein, may be released both during digestion in the gastrointestinal tract and during food processing (Korhonen et al. 1998; Korhonen and PihlantoLeppälä 2006). Food protein hydrolysates are natural ingredients, and therefore they are believed to be safe for consumers when they are served as functional foods. Studies indicate the potential of using egg white protein hydrolysates as functional products with the anti-diabetic activity as the inhibitor of $\alpha$-glucosidase (Yu et al. 2011). Peptides derived from sardine muscle hydrolysate, digested with Bacillus licheniformis alkaline protease expressed similar activity (Matsui et al. 1999). The $\alpha$-glucosidase inhibitory activity of dairy protein hydrolysates has been reported recently (Lacroix and Li-Chan 2013).

Many milk-derived peptides reveal multifunctional properties, i.e. specific peptide sequences with two or more different biological activities. As shown by many researchers, both casein and whey protein may be an important source of peptides with bioactive properties. For example, whey proteins can be a source of dipeptidyl dipeptidase IV inhibitors (Tulipano et al. 2011). Milk protein-derived peptides are claimed to be health enhancing components that can be used to reduce the risk of disease or to enhance a certain physiological function.

Among the different classes of bioactive peptides, the antihypertensive peptides are the best known. ACE inhibitory peptides have been discovered in various food sources such as milk, gelatine, maize and soybean (Meisel 1997; Oshima et al. 1979; Miyoshi et al. 1991, Okamoto et al. 1995). Antihypertensive peptides have been found in processed dairy products. ACE inhibitors derived from milk proteins represent different fragments of casein (casokinins) or whey proteins (lactokinins) (Nakamura et al. 1995; Korhonen and Pihlanto-Leppälä 2006). Two potent ACEinhibitory peptides from $\beta$-casein, f84-f86, which corresponds to Val-Pro-Pro, and f74-f76, which corresponds to Ile-Pro-Pro, and one from k-casein, f108-f110, which corresponds to Ile-Pro-Pro, were purified from the Japanese soft drink "Calpis", made from bovine skim milk fermented with Lactobacillus helveticus and Saccharomyces cerevisiae (Nakamura et al. 1995). The results of Pihlanto's research demonstrate the existence of several biologically active whey-derived peptides and hydrolysates (Pihlanto 2000).

Whey proteins are significantly resistant to hydrolysis and the use of enzymes significantly increases the cost of their production. One of the promising alternatives is the use of plant serine protease isolated from $C$. ficifolia, exhibiting attractive proteolytic properties towards casein, protein from corn gluten meal (CGM) or ovoalbumin (Illanes et al. 1985; Curotto et al. 1989; Pokora et al. 2014). The protease exhibits a very high and broad $\mathrm{pH}$ optimum with a maximum at 10.7 and is able to cleave four bonds in an endogenous serine proteinase inhibitor. The optimum temperature is $35^{\circ} \mathrm{C}$ and optimum $\mathrm{pH}$ is 8.6 (Dryjański et al. 1990). Taking this into account we used serine protease from $C$. ficifolia to hydrolyze whey proteins to generate peptides with antidiabetic and antyhipertensive activities.

The aim of this study is to investigate peptides generated from whey proteins hydrolyzed by the non-commercial proteolytic enzyme obtained from Asian pumpkin as the natural sources of DPP-IV, $\alpha$-glucosidase and ACE inhibitors that can be used as functional food ingredients for the complex management of type 2 diabetes and hypertension.

\section{Materials and Methods}

Isolation of the Enzyme

Serine protease was isolated from Asian pumpkin according to the method of Dryjański et al. (1990). After 
separating the peel from the seeds, the pulp was homogenized and centrifuged at 5,000 $\times g, 20 \mathrm{~min}$. Clear supernatant was added to solid ammonium sulphate in order to achieve $30 \%$ saturation. The final precipitate was collected by centrifugation at $5,000 \times g, 20 \mathrm{~min}$. Desalting was conducted by dialysis in water. The specific activity of the enzyme preparation was $4,411 \mathrm{U} / \mathrm{g}$.

\section{Substrates}

$\beta$-lactoglobulin was provided by Sigma (L3908) and the whey protein concentrate (WPC-80), manufactured from sweet whey and spray-dried, was provided by Davisco Foods Iternational, Inc.

\section{Determination of Enzyme Activity}

Proteolytic activity of the serine protease was determined with the use of $2 \%$ casein as a substrate in $0.1 \mathrm{M}$ Tris- $\mathrm{HCl}$ at $\mathrm{pH}$ 8.6. The substrate was incubated with the enzyme for $10 \mathrm{~min}$ at $37{ }^{\circ} \mathrm{C}$. After this time the reaction was stopped by the addition of $5 \%$ trichloroacetic acid (TCA). The sample was then centrifuged and absorbance measured at $\lambda=280 \mathrm{~nm}$. One unit of enzyme activity was defined as the amount of enzyme giving an increase in absorbance of 0.1 under conditions described above (Chrzanowska and Kołaczkowska 1998).

\section{Determination of Protein Content}

Protein content was determined by colorimetric method of Lowry et al. (1951), using BSA (Sigma, P0834) as a standard.

\section{Hydrolysis of $\beta$-Lactoglobulin and WPC-80}

Enzymatic hydrolysis of $1 \% \beta$-lactoglobulin and $1 \%$ WPC-80 solution was conducted using serine protease isolated from Asian pumpkin at the dose of $150 \mathrm{U} / \mathrm{mg}$ of hydrolyzed protein. The reaction was carried out at $37{ }^{\circ} \mathrm{C}$ for $5 \mathrm{~h}$ in $0.1 \mathrm{M}$ Tris-HCl buffer at $\mathrm{pH}$ 8.0. The hydrolysis was terminated by thermal inactivation (for biological activity determinations) or by the addition of $10 \%$ trichloroacetic acid (TCA) $(1: 1 \mathrm{~V} / \mathrm{V})$.

\section{Ultrafiltration}

5-hour hydrolysates were partially fractionated by ultrafiltration with Amicon Ultra-15 Millipore membranes with cut-offs equal 3 and $10 \mathrm{kDa}$. The separated permeates were vacuum concentrated.
Reversed-Phase High Performance Liquid Chromatography (RP-HPLC)

Peptide profiles were determined by RP-HPLC with an Agilent 1100 Series system. The peptide preparations were solubilized in the even volume of phase A $(0.1 \%$ TFA in $\mathrm{H}_{2} \mathrm{O}$ ) before loading on the chromatographic HPLC column (Zorbax Eclipse XDB-C18 Agilent column $(50 \times 4.6 \mathrm{~mm})$. Separation was performed at a flow rate of $1 \mathrm{~mL} / \mathrm{min}$ at $30{ }^{\circ} \mathrm{C}$. Peptide fractions, varying in hydrophobicity, eluted from the column in linear gradient of phase B $(0.1 \%$ TFA in acetonitrile), were collected and lyophilized. Absorbance measurement was made at $\lambda=230 \mathrm{~nm}$ (DAD, G1315B). After resuspension of peptide fractions in Mili-Q water, their inhibitory activity was determined. Further peptide separation was performed using a Zorbax XDB-C18 Agilent column $(250 \times 4.5 \mathrm{~mm})$. The absorbed peptides were eluted with a gradient $(0-100 \%)$ of phase B. Other analysis conditions are described above (Ardo and Gripon 1995).

The Degree of Hydrolysis

The course of the hydrolysis was monitored by the determination of soluble peptide concentration in $5 \%$ TCA in relation to the total protein. The concentration of the trichloroacetic acid-soluble product in the supernatant was measured spectrophotometrically at $\lambda 280 \mathrm{~nm}$ (Spellman et al. 2003).

\section{The Free Amino Groups Content}

The content of free amino groups (FAG) ( $\mu \mathrm{mol} \mathrm{Gly/g}$ ) was determined using trinitrobenzene sulfonic acid (TNBS, Sigma) according to the method described by Kuchroo et al. (1983). Samples of hydrolysate were diluted with $0.1 \mathrm{~mol} / \mathrm{L}$ borate buffer to the final volume of $2 \mathrm{~mL}$, then mixed with $50 \mu \mathrm{L}$ of TNBS reagent $(0.03 \mathrm{~mol} / \mathrm{L})$ and incubated in the dark for $2 \mathrm{~h}$ at room temperature. The reaction was stopped by adding $2 \mathrm{~mL}$ of $0.1 \mathrm{~mol} / \mathrm{L}$ sodium phosphate containing $1.5 \mathrm{mmol} / \mathrm{L}$ sodium sulfate and the absorbance was measured spectrophotometrically at $\lambda$ $420 \mathrm{~nm}$. The results were expressed as $\mu \mathrm{mol} \mathrm{Gly} / \mathrm{g}$ in relation to a standard curve prepared with the defined concentration of glycine.

\section{ACE-Inhibitory Activity}

ACE-inhibitory activity $\left(\mathrm{IC}_{50}\right)$ was assayed by the spectrophotometric method with the use of hippury-L-histydylL-leucine (HHL) (Sigma, H4884) as substrate (Miguel et al. 2007). HHL ( $5 \mathrm{mmol} / \mathrm{L}$ in $100 \mathrm{mmol} / \mathrm{L}$ potassium phos-

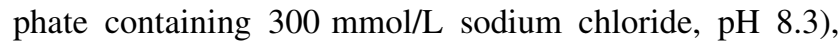
enzyme (ACE from rabbit lung, Sigma, A6778) and 
peptide solutions were incubated at $37{ }^{\circ} \mathrm{C}$ for $30 \mathrm{~min}$. The reaction was stopped with the addition of $1 \mathrm{~mol} / \mathrm{L} \mathrm{HCl}$. Conversion of HHL to hippurate and L-histidyl-L-leucine was quantified spectrophotometrically at $\lambda 228 \mathrm{~nm}$. The $\mathrm{IC}_{50}$ was defined as the concentration of inhibitor required to inhibit $50 \%$ of the ACE activity.

\section{a-Glucosidase Inhibitory Activity}

The $\alpha$-glucosidase-inhibition assay was performed according to the method of Yu et al. (2011). $\alpha$-Glucosidase from Saccharomyces cerevisiae (Sigma, G0660) hydrolyzed the substrate- $p$-nitro phenyl glucopyranoside (pNPG) (Sigma, N1377), and the thus produced $p$-nitro phenol can be measured through the absorbance at the $\lambda$ $410 \mathrm{~nm}$. The $\mathrm{IC}_{50}$ was defined as the concentration of inhibitor required to inhibit $50 \%$ of the $\alpha$-glucosidase activity under the assay conditions.

\section{DPP-IV-Inhibitory Activity}

DPP-IV-inhibitory activity $\left(\mathrm{IC}_{50}\right)$ was determined using a modified method of Lacroix and Li-Chan (2013). DPP-IV from porcine kidney was provided by Sigma (D7052). The lyophilized peptide fractions were resuspended in $0.1 \mathrm{M} / \mathrm{L}$ Tris- $\mathrm{HCl}$ buffer, $\mathrm{pH}$ 8.0. The test sample $(25 \mu \mathrm{L})$ was preincubated with the equal volume of the substrate GlyPro- $p$-nitroanilide (1.6 mM) (Sigma, G0513) at $37{ }^{\circ} \mathrm{C}$ for $10 \mathrm{~min}$. Afterwards, $50 \mu \mathrm{L}$ of DPP-IV $(0.01 \mathrm{U} / \mathrm{mL}$, in $0.1 \mathrm{M} / \mathrm{L}$ Tris- $\mathrm{HCl}$ buffer, $\mathrm{pH}$ 8.0) was added and the mixture was incubated at $37^{\circ} \mathrm{C}$ for $60 \mathrm{~min}$. The reaction was stopped by the addition of $100 \mu \mathrm{L}$ of $1 \mathrm{M} / \mathrm{L}$ sodium acetate buffer, $\mathrm{pH}$ 4.0. The released $p$-nitroanilide as a hydrolysis product was measured at $\lambda 405 \mathrm{~nm}$. The $\mathrm{IC}_{50}$ was defined as the concentration of inhibitor required to inhibit $50 \%$ of the DPP-IV activity under the assay conditions.

\section{Statistical Analysis}

All assays were conducted in triplicate. The results were analyzed using analysis of variance (ANOVA) in Statistica 7.0 software. Significance was set at the level of $p \leq 0.05$.

\section{Results and Discussion}

\section{Extent of Hydrolysis}

The course of the enzymatic hydrolysis of the whey proteins was monitored by the determination of the degree of hydrolysis $[\mathrm{DH}](\%)$. The determined $\mathrm{DH}$ for $\beta$-lactoglobulin and WPC-80 after 5 h hydrolysis reached $27.3 \%$ and $30.5 \%$, respectively. During the protein degradation in all hydrolysates also the proportional increase in the FAG content was observed. The final concentration of released FAG reached $2516 \mu \mathrm{mol} \mathrm{Gly/g}$ and $2924 \mu \mathrm{mol} \mathrm{Gly/g}$ for $\beta$-lactoglobulin hydrolysate and WPC-80 hydrolysate, respectively. The progress of hydrolysis was also confirmed by RP-HPLC peptide profiles analysis (Fig. 1). On the chromatograms of hydrolysates obtained after $5 \mathrm{~h}$ of reaction, the presence of subfractions was noted, which were eluted from the column at low concentration of acetonitrile and varied in terms of hydrophobicity. The majority of peptides were eluted at $\mathrm{ACN}$ concentration of 35-40\%.

Hydrolysates of $\beta$-lactoglobulin and WPC-80 were ultrafiltrated with 3 and $10 \mathrm{kDa}$ membranes, and thus permeates of the molecular mass below $3 \mathrm{kDa}$ and ranging from 3 to $10 \mathrm{kDa}$ were distinguished. Each permeate was further fractionated using the RP-HPLC method (Fig. 2), which resulted in 14 and 12 fractions for $\beta$-lactoglobulin and 15 and 20 for WPC-80 hydrolysates, respectively.

\section{DPP-IV Inhibition}

The vast majority of all collected fractions revealed significant ability to inhibit the activity of DPP-IV (Fig. 3a-d). The only exception were five $\beta$-lactoglobulin-derived peptide fractions within the 3-10 kDa range (Fig. 3b). Although the inhibition of DPP-IV activity was observed in all the fractions obtained from the WPC- 80 hydrolysate, the peptide fractions below $3 \mathrm{kDa}$ showed the greatest potency at $\mathrm{IC}_{50}<0.55 \mathrm{mg} / \mathrm{mL}$ (Fig. 3c). However, it was fraction no. 10 (WPC-80 peptides in the $3-10 \mathrm{kDa}$ range) exhibited the highest activity against this enzyme (Fig. 3d). A concentration of $0.07 \mathrm{mg} / \mathrm{mL}$ was required in order to decrease the activity of the enzyme to $50 \%$. The results obtained for fractions derived from WPC with $3-10 \mathrm{kDa}$ were different than the results obtained for $\beta$-lactoglobulin (Fig. 3b, d).

It is possible that peptides released from other whey protein components contributed to the activity detected for the hydrolysate obtained from WPC. In the research of Lacroix and Li-Chan (2013) all the products of the peptic treatment of whey protein isolate: $\beta$-lactoglobulin, $\alpha$-lactalbumin, bovine serum albumin and lactoferrin present at a concentration of $500 \mu \mathrm{g} / \mathrm{mL}$ caused significant inhibition of the DPP-IV enzyme. The $\mathrm{IC}_{50}$ values defined in the cited research were: 0.075 and $1.28 \mathrm{mg} / \mathrm{mL}$ for WPI and $\beta$-lactoglobulin hydrolysates, respectively (Lacroix and LiChan, 2013).

Another study also confirmed that whey proteins have peptide sequences with potential DPP-IV inhibitory activity. Tryptic hydrolysate of $\beta$-lactoglobulin displayed the inhibitory activity that reached $\mathrm{IC}_{50}=210 \mu \mathrm{M}$ (Agyei and Danquah, 2011). This is in the line with results obtained by 


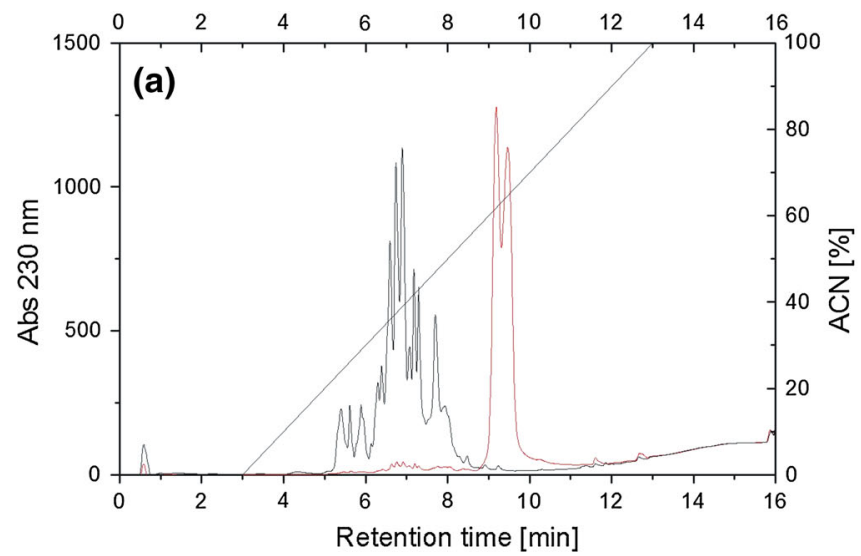

Fig. 1 RP-HPLC profiles of peptide fractions (black) obtained after $5 \mathrm{~h}$ hydrolysis of a $\beta$-lactoglobulin and b WPC-80 with serine protease isolated from Asian pumpkin (Cucurbita ficifolia) introduced

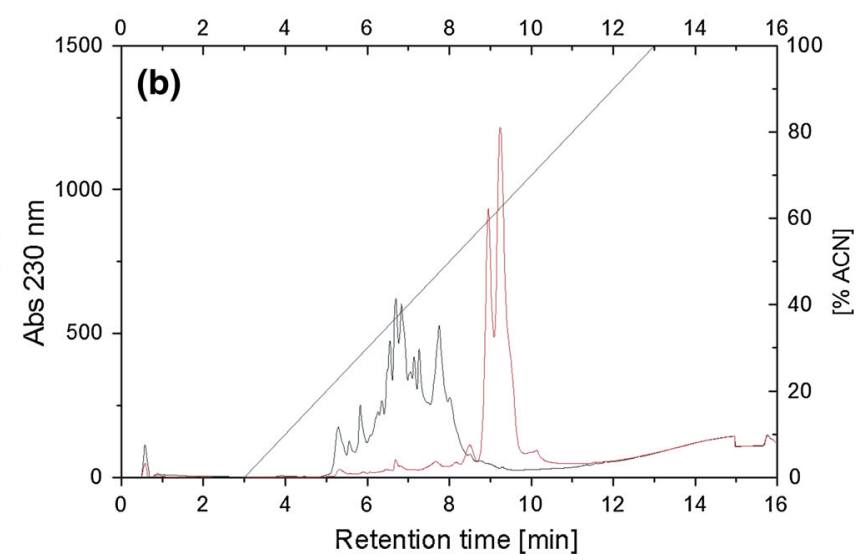

at the dose of $150 \mathrm{U} / \mathrm{mg}$. Undigested $1 \%$ protein solution was use as control of hydrolysis (red) (Color figure online)
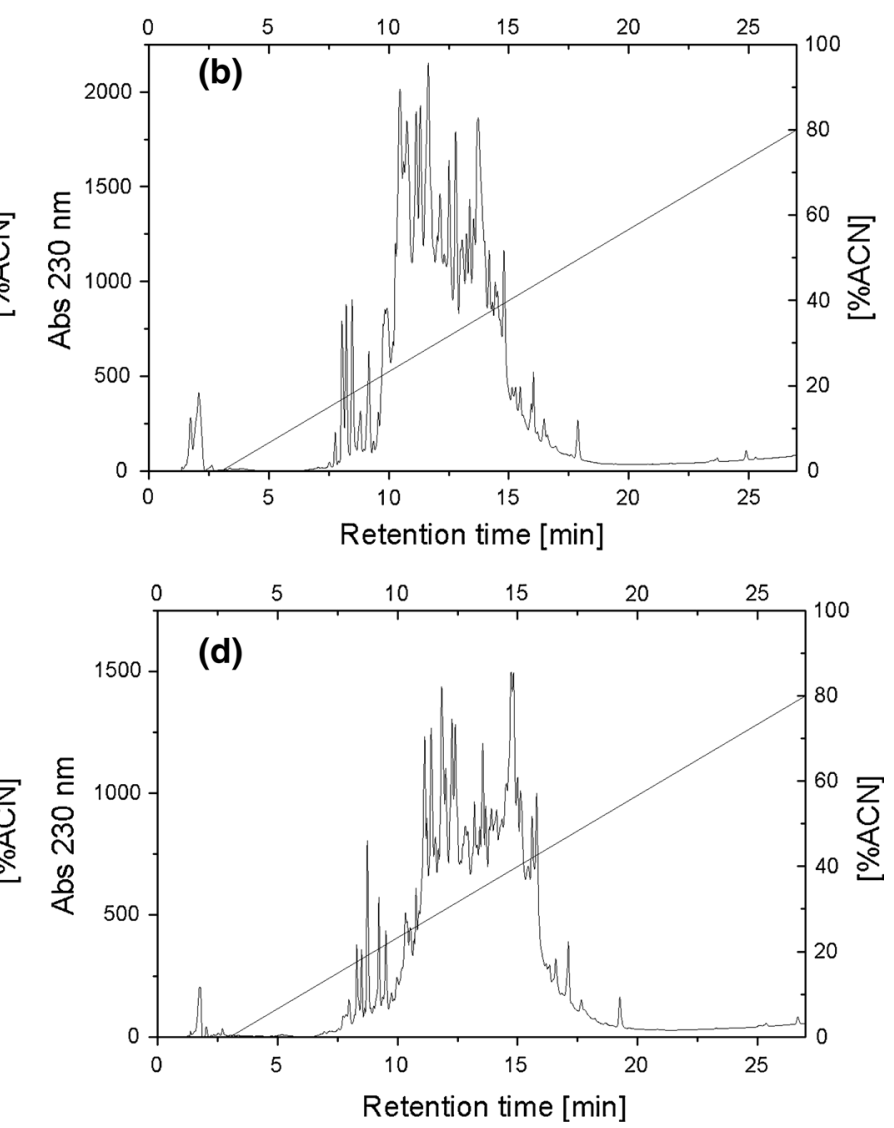

Fig. 2 RP-HPLC peptide profiles of permeates obtained after ultrafiltration a $\beta$ - lactoglobulin $<3 \mathrm{kDa}$, b $\beta$-lactoglobulin $3-10 \mathrm{kDa}$, c WPC-80 $<3 \mathrm{kDa}$, WPC-80 3-10 kDa

Silveira et al. (2013), who reported that peptide fractions isolated from tryptic hydrolysate of WPC can be an effective DPP-IV inhibitor. Among six peptide fractions which were previously separated by RP-HPLC the most potent fragment, IPAVF $\left(\mathrm{IC}_{50}=44.7 \mu \mathrm{M}\right)$, corresponded to $\beta$-lactoglobulin $\mathrm{f}(78-82)$ (Silveira et al. 2013).

\section{a-Glucosidase Inhibition}

The whey protein hydrolysates obtained by the whey protein degradation with the use of serine protease from $C$. ficifolia were also assessed for their inhibitory activity against $\alpha$-glucosidase (Fig. $4 \mathrm{a}-\mathrm{d}$ ). Among fifteen peptide 

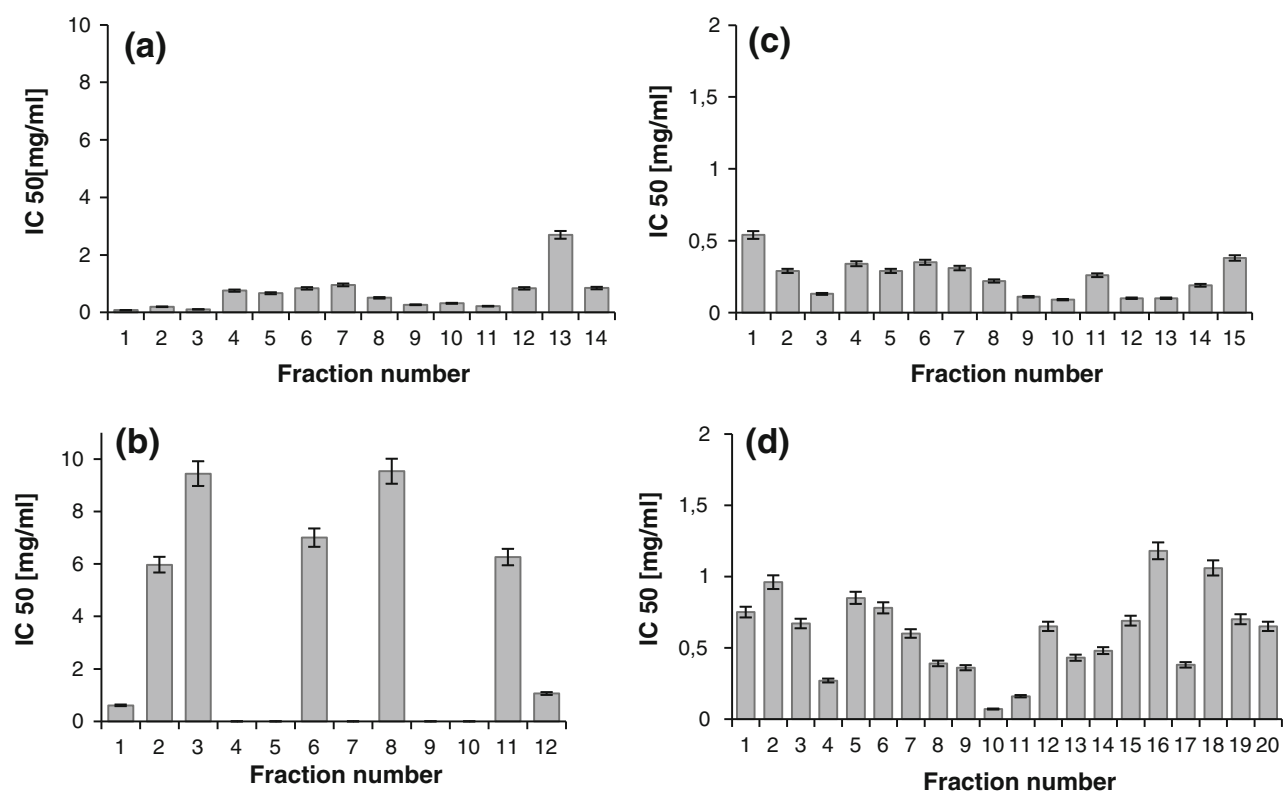

Fig. 3 DPP-IV inhibitory activity of $\beta$-lactoglobulin $(\mathbf{a}, \mathbf{b})$ and WPC derived peptide fractions $(\mathbf{c}, \mathbf{d})$. $\beta$-lactoglobulin fractions of molecular mass $<3 \mathrm{kDa}(\mathbf{a}), 3-10 \mathrm{kDa}(\mathbf{b})$. WPC fractions of molecular mass

$<3 \mathrm{kDa}(\mathbf{c}), 3-10 \mathrm{kDa}$ (d). DPP-IV inhibitory activity was reported as IC50 i.e. the concentration of the inhibitor required to inhibit $50 \%$ of the DPP-IV activity under the assay conditions
Fig. $4 \alpha$-Glucosidase inhibitory activity of $\beta$-lactoglobulin (a, b) and WPC derived peptide fractions $(\mathbf{c}, \mathbf{d})$. $\beta$-lactoglobulin fractions of molecular mass $<3 \mathrm{kDa}(\mathbf{a}), 3-10 \mathrm{kDa}(\mathbf{b})$. WPC fractions of molecular mass $<3 \mathrm{kDa}(\mathbf{c}), 3-10 \mathrm{kDa}(\mathbf{d})$. $\alpha$-Glucosidase inhibitory activity was reported as IC50 i.e. the concentration of the inhibitor required to inhibit $50 \%$ of the DPP-IV activity under the assay conditions
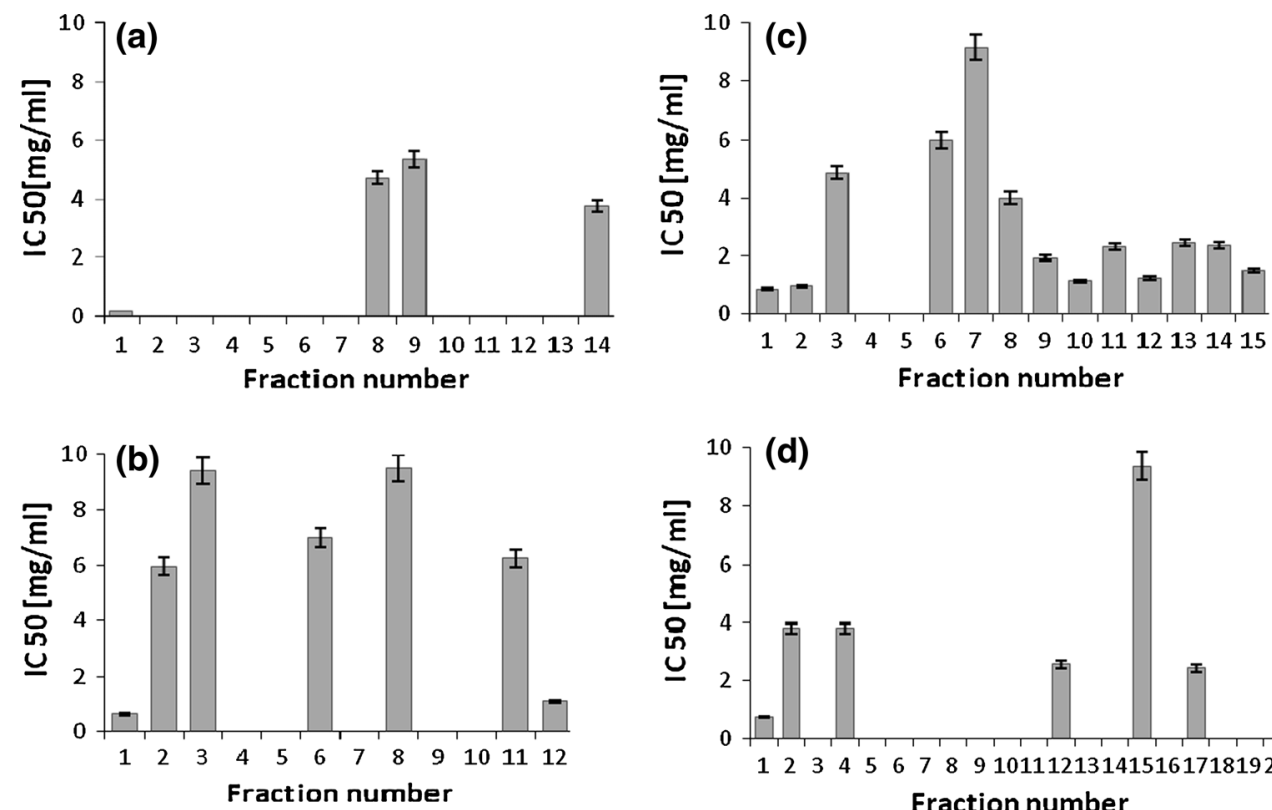

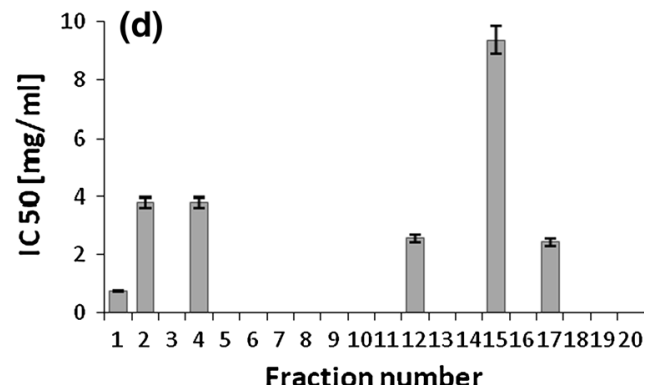

fractions derived from the WPC-80 hydrolysate with the molecular mass below $3 \mathrm{kDa}$, thirteen exhibited $\alpha$-glucosidase inhibitory activity (Fig. 4c). Within this group six fractions showed the greatest potency with the $\mathrm{IC}_{50}$ values below $2.0 \mathrm{mg} / \mathrm{mL}$. However, when we compared the results with those of $\beta$-lactoglobulin peptide fractions of the same molecular mass range, only four fractions displayed the inhibiting activity. The relatively low inhibitory activity was surprising because $\beta$-lactoglobulin is the major protein fraction in whey. In addition, in the paper of Lacroix and Li-Chan (2013), $\alpha$-lactalbumin, lactoferrin and serum albumin hydrolysates obtained by peptic digestion were able to inhibit the activity of $\alpha$-glucosidase.

The only study on $\alpha$-glucosidase inhibitory activity of whey protein hydrolysates was conducted by Lacroix and Li-Chan (2013). The inhibitory activity towards $\alpha$-glucosidase was observed only in case of WPI ( $\left.\mathrm{IC}_{50}=4.5 \mathrm{mg} / \mathrm{mL}\right)$ and $\beta$-lactoglobulin $\left(\mathrm{IC}_{50}=3.5 \mathrm{mg} / \mathrm{mL}\right)$. The different 

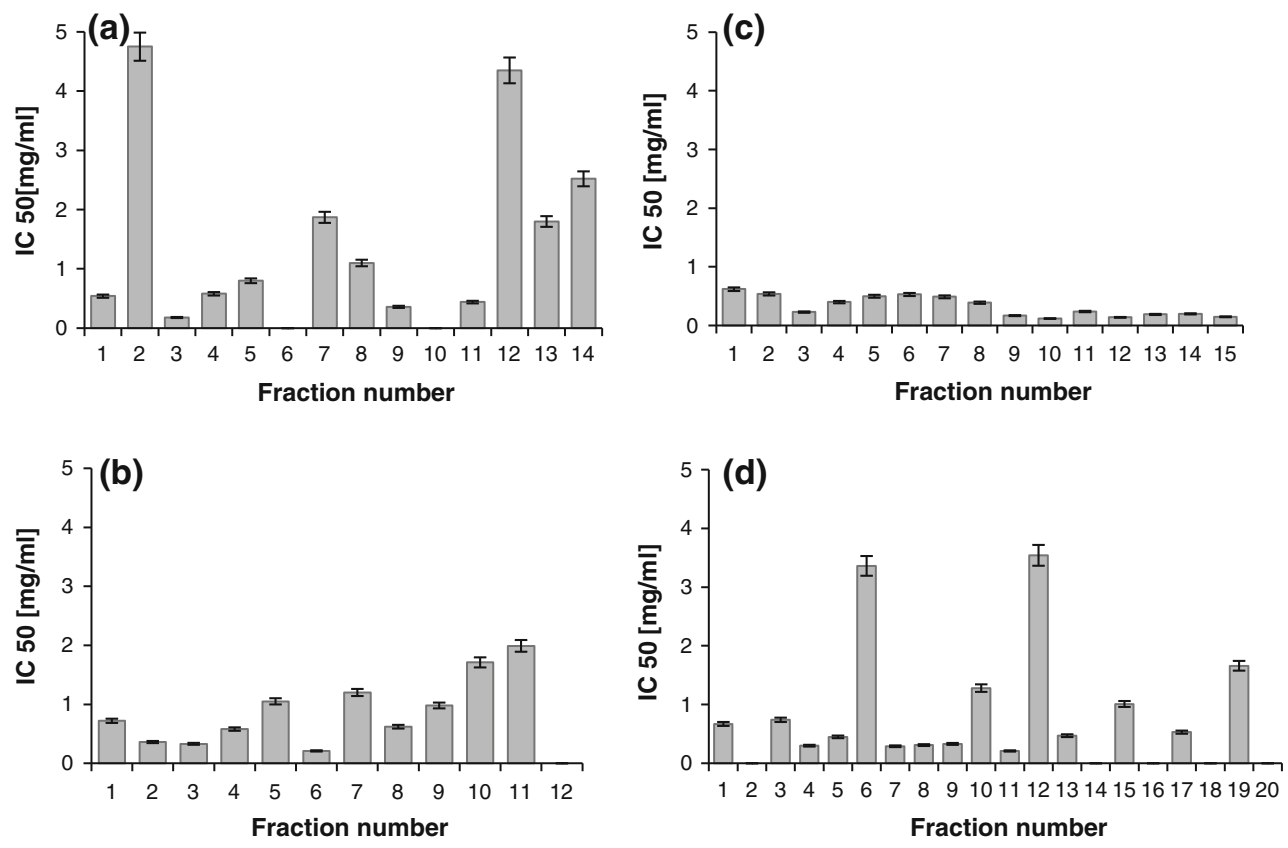

Fig. 5 ACE inhibitory activity of $\beta$-lactoglobulin (a, b) and WPC derived peptide fractions $(\mathbf{c}, \mathbf{d})$. $\beta$-lactoglobulin fractions of molecular mass $<3 \mathrm{kDa}(\mathbf{a}), 3-10 \mathrm{kDa}(\mathbf{b})$. WPC fractions of molecular mass

$<3 \mathrm{kDa}(\mathbf{c}), 3-10 \mathrm{kDa}(\mathbf{d})$. ACE inhibitory activity was reported as IC50 i.e. the concentration of the inhibitor required to inhibit $50 \%$ of the DPP-IV activity under the assay conditions

levels of this activity in their study might have resulted from the use of rat intestinal $\alpha$-glucosidase in the assay (Lacroix and Li-Chan, 2013). Some synthetic inhibitors show different ability to inhibit the activity of $\alpha$-glucosidase depending on the enzyme origin. They strongly affect the activity of mammalian $\alpha$-glucosidase, but have little inhibitory effect on baker's yeast $\alpha$-glucosidase (Oki et al. 1999). On the other hand, some food products such as yogurt, chicken essence and fish sauce, exhibit inhibitory activity only against yeast $\alpha$-glucosidase (Oki et al. 1999). Moreover, Lacroix and Li-Chan in their study used pepsin in the hydrolysis. Probably the different traits of pepsin and serine protease from $C$. ficifolia were the most important factor affecting the biological activity of hydrolysates.

Our results indicate that $\beta$-lactoglobulin-derived peptides of the molecular mass 3-10 kDa coincide with those obtained from WPC-80. However, the WPC-80 derived peptides showed greater potency than those originated from $\beta$-lactoglobulin. Five of the six fractions had $\mathrm{IC}_{50}$ below $4.0 \mathrm{mg} / \mathrm{mL}$ (Fig. 4d). These observations are in line with results obtained by Matsui et al. (1999) and by Yu et al. (2011) who reported the similar levels of $\alpha$-glucosidase inhibitory activity of other food protein hydrolysates. Matsui et al. (1999) showed that an alkaline protease hydrolysate from sardine muscle was able to inhibit the carbohydrate-hydrolyzing enzyme with $\mathrm{IC}_{50}$ at $48.7 \mathrm{mg} /$ $\mathrm{mL}$. More recently, the hexapeptide Arg-Val-Pro-Ser-LeuMet $\quad\left(\mathrm{IC}_{50}=23.07 \mu \mathrm{M}\right.$ or $\left.\sim 0.016 \mathrm{mg} / \mathrm{mL}\right)$ and the

pentapeptide Thr-Pro-Ser-Pro-Arg $\left(\mathrm{IC}_{50}=40.02 \mu \mathrm{M}\right.$ or $\sim 0.022 \mathrm{mg} / \mathrm{mL}$ ), derived from egg white protein, were reported to possess $\alpha$-glucosidase inhibitory activity.

\section{ACE Inhibition}

The whey protein hydrolyzed by serine protease from $C$. ficifolia were also tested for their inhibitory activity against the ACE (Fig. 5a-d). Vast majority of all the collected fractions exhibited the ability to inhibit ACE. The highest activity was observed in case of the WPC- 80 hydrolysate with the peptide fractions up to $3 \mathrm{kDa}$ (Fig. 5c), showing the greatest potency at $\mathrm{IC}_{50}$ below $0.65 \mathrm{mg} / \mathrm{mL}$. A relatively lower inhibitory activity of the hydrolyzed $\beta$-lactoglobulin samples was observed. Six fractions originated from $\beta$-lactoglobulin peptides of molecular masses below $3 \mathrm{kDa}$, with $\mathrm{IC}_{50}$ below $0.8 \mathrm{mg} / \mathrm{mL}$ (Fig. 5 a). The inhibitory activity of six fractions ranged between 1.1 and $4.75 \mathrm{mg} / \mathrm{mL}$, whilst two fractions did not inhibit ACE. In comparison, WPC-80 derived peptides of molecular size 3-10 kDa contained five inactive fractions (Fig. 5d). However, the determined activity expressed by $\mathrm{IC}_{50}$ values in ten preparations did not exceed the level of $0.8 \mathrm{mg} / \mathrm{mL}$. In case of $\beta$-lactoglobulin derived peptides of molecular size 3-10 kDa only one preparation did not exhibit inhibitory activity against the ACE. Six fractions were able to decrease the activity of the enzyme to $50 \%$ of the maximum at a concentration below $0.8 \mathrm{mg} / \mathrm{mL}$ (Fig. $5 \mathrm{~b}$ ). 
According to Hartmann and Meisel (2007), ACEinhibitory peptides are generally short-chain and contain polar amino acid residues in their structure. Other authors demonstrate that ACE inhibition is mainly attributable to peptides with molecular masses lower than $3 \mathrm{kDa}$ (Miguel et al. 2004; Saiga et al. 2006). The hypotensive peptides Val-Pro-Pro and Ile-Pro-Pro, for example, can be released from $\beta$-casein and $\kappa$-casein by enzymes obtained from Lactobacillus helveticus (Miguel et al. 2004). Other authors report that ACE-inhibitory activity is stronger in case of dipeptides, such as -His-Leu, -Phe-Arg, or -Ala-Pro (Saiga et al. 2006; Miguel et al. 2007). On the other hand longer-chain peptides present in egg-white peptic hydrolysate (RADHPFL and YAEERYPIL) can also exert ACEinhibitory activity. Saiga et al. (2006) also found an ACEinhibitory long-chain peptide (Gly-Phe-Hyp-Gly-Thr-HypGly-Leu-Hyp-Gly-Phe), in an extract of chicken breast muscle hydrolyzed by gastric enzymes (trypsin-chymotrypsin and small intestinal enzymes).

Most of the tested peptides with inhibitory properties against DPP-IV were able to inhibit ACE simultaneously. This was exhibited by each of the fifteen WPC- 80 derived peptide fractions up to $3 \mathrm{kDa}$. Moreover, within this group thirteen preparations were capable of inhibiting the activity of the three tested enzymes. The triple inhibition was observed also in the case of four peptide fractions of $\beta$-lactoglobulin up to $3 \mathrm{kDa}$, four $\beta$-lactoglobulin fractions from 3 to $10 \mathrm{kDa}$ and five WPC- 80 fractions from 3 to $10 \mathrm{kDa}$.

\section{Conclusion}

The results of the present study demonstrate that hydrolysis of either $\beta$-lactoglobulin or WPC-80 by the noncommercial serine protease isolated from Asian pumpkin (Cucurbita ficifolia) resulted in the production of peptides with inhibitory properties against DPP-IV, $\alpha$-glucosidase and ACE. These findings suggest that whey protein hydrolysates with such inhibitory traits may potentially improve blood glucose regulation by means of their ability to slow both the inactivation of the incretin hormones and the intestinal digestion of carbohydrates and also decrease other complications associated with diabetes. However, further research is needed for the better understanding of molecular mechanisms of action of the defined peptides. In addition, clinical studies are necessary in order to confirm the efficiency and bioavailability of whey protein-derived peptides in humans.

Acknowledgments This work was financially supported by the National Science Center. Project No. 2011/01/B/NZ9/04297.
Open Access This article is distributed under the terms of the Creative Commons Attribution License which permits any use, distribution, and reproduction in any medium, provided the original author(s) and the source are credited.

\section{References}

Agyei D, Danquah MK (2011) Industrial-scale manufacturing of pharmaceutical-grade bioactive peptides. Biotechnol Adv 29:272-277

Ardo Y, Gripon JC (1995) Comparative study of peptidolysis in some semi-chard round eyed cheese varieties with different fat contents. J Dairy Res 62:543-547

Blanco J, Nguyen C, Callebaut C, Jacotot E, Krust B, Mazaleyrat JP, Wakselman M, Hovanessian AG (1998) Dipeptidyl-peptidase IV- $\beta$. Further characterization and comparison to dipeptidylpeptidase IV activity of CD26. Eur J Biochem 256:369-378

Buttar HS, Li T, Ravi N (2005) Prevention of cardiovascular diseases: Role of exercise, dietary interventions, obesity and smoking cessation. Exp Clin Cardiol 10:229-249

Chrzanowska J, Kołaczkowska M (1998) Production of extracellular proteolytic enzymes by Beauveria bassiana. Acta Mycol 33:277-285

Curotto E, Gonzáles G, O'Reilly S, Tapia G (1989) Isolation and partial characterization of protease from Cucurbita ficifolia. FEBS Lett 243:363-365

Deacon CF (2011) Dipeptidyl peptidase-4 inhibitors in the treatment of type 2 diabetes: a comparative review. Diabetes Obes Metab 13:7-18

Dryjański M, Otlewski J, Polanowski A, Wilusz T (1990) Serine proteinase from Cucurbita ficifolia seed; purification, properties, substrate specificity and action on native squash trypsin inhibitor (CMTI I). Biol Chem 371:889-895

Go AS, Mozaffarian D, Roger VL, Benjamin EJ, Berry JD, Borden WB, Bravata DM, Dai S, Ford ES, Fox CS, Franco S, Fullerton HJ, Gillespie C, Hailpern SM, Heit JA, Howard VJ, Huffman MD, Kissela BM, Kittner SJ, Lackland DT, Lichtman JH, Lisabeth LD, Magid D, Marcus GM, Marelli A, Matchar DB, McGuire DK, Mohler ER, Moy CS, Mussolino ME, Nichol G, Paynter NP, Schreiner PJ, Sorlie PD, Stein J, Turan TN, Virani SS, Wong ND, Woo D, Turner MB (2013) Heart disease and stroke statistics-2013 update: a report from the American Heart Association. Circulation 127:6-245

Haque E, Chand R (2008) Antihypertensive and antimicrobial bioactive peptides from milk proteins. Eur Food Res Technol 227:7-15

Hartmann R, Meisel H (2007) Food-derived peptides with biological activity: from research to food applications. Cur Opin Biotech 18:163-169

Hildebrandt M, Reutter W, Arck P, Rose M, Klapp BF (2000) A guardian angel: the involvement of dipeptidyl peptidase IV in psychoneuroendocrine function, nutrition and immune defence. Clin Sci 99:93-104

Holman RR, Paul SK, Bethel MA, Matthews DR, Neil HA (2008) 10-year follow-up of intensive glucose control in type 2 diabetes. N Eng J Med 359:1577-1589

Huang SL, Jao CL, Ho KP, Hsu KC (2012) Dipeptidyl-peptidase IV inhibitory activity of peptides derived from tuna cooking juice hydrolysates. Peptides 35:114-121

Illanes A, Schaffeld G, Schiappacasse C, Zuñiga M, González G, Curotto E, Tapia G, O'Reilly S (1985) Some studies on the protease from a novel source: the plant Cucurbita ficifolia. Biotechnol Lett 7:669-672

Ionescu SD, Sandru V, Leuciuc E, Manea P, Burdujan A, Tovarniţchi S, Cosovanu A (2002) Undesirable effects and interaction to 
angiotensin converting enzyme inhibitors therapy. Rev Med Chir Soc Med Nat Iasi 106:128-131

Jaiswal N, Srivastava SP, Bhatia V, Mishra A, Sonkar AK, Narender T, Srivastava AK, Tamrakar AK (2012) Inhibition of alphaglucosidase by Acacia nilotica prevents hyperglycemia along with improvement of diabetic complications via aldose reductase inhibition. J Diabetes Metab 6:1-7

Kitts DD, Weiler K (2003) Bioactive proteins and peptides from food sources. Applications of bioprocesses used in isolation and recovery. Curr Pharm Des 9:1309-1323

Korhonen H, Pihlanto-Leppälä A (2006) Bioactive peptides: production and functionality. Int Dairy J 16:1-15

Korhonen H, Pihlanto-Leppälä A, Rantamäki P, Tupasela T (1998) Impact of processing on bioactive proteins and peptides. Trends Food Sci Technol 9:307-319

Kuchroo CV, Ramilly IP, Fox PF (1983) Assesment of proteolysis in cheese by reaction with trinitrobenzosulfonic acid. J Food Technol 7:129-133

Lacroix IME, Li-Chan ECY (2013) Inhibition of dipeptidyl peptidase (DPP)-IV and $\alpha$-glucosidase activities by pepsin-treated whey proteins. J Agric Food Chem 61:7500-7506

Lowry OH, Rosebrough J, Farr AL, Randall RJ (1951) Protein measurement with the folin phenol reagent. J Biol Chem 193:265-275

Matsui T, Oki T, Osajima Y (1999) Isolation and identification of peptidic alpha-glucosidase inhibitors derived from sardine muscle hydrolysate. Z Naturforsch 54:259-263

Meisel H (1997) Biochemical properties of regulatory peptides derived from milk proteins. Biopolymers 43:119-128

Miguel M, Recio I, Gómez-Ruiz JA, Ramos M, López-Fandiño R (2004) Angiotensin I-converting enzyme inhibitory activity of peptides derived from egg white proteins by enzymatic hydrolysis. J Food Prot 67:1914-1920

Miguel M, Alonso MJ, Salaices M, Aleixandre A, Lopez-Fandino R (2007) Antihypertensive, ACE-inhibitory and vasodilator properties of an egg white hydrolysate: effect of a simulated intestinal digestion. Food Chem 104:163-168

Miyoshi S, Ishikawa H, Kaneko T, Fukui F, Tanaka H, Maruyama S (1991) Structures and activity of angiotensin-converting enzyme inhibitors in an alpha-zein hydrolysate. Agric Biol Chem 55:1313-1318

Nakamura Y, Yamamoto N, Sakai K, Takano T (1995) Antihypertensive effect of sour milk and peptides isolated from it that are inhibitors to angiotensin I-converting enzyme. J Dairy Sci 78:1253-1257

Okamoto A, Hanagata H, Kawamura Y, Yanagida F (1995) Anti hypertensive substances in fermented soybean, natto. Plant Foods Hum Nutr 47:39-47

Oki T, Matsui T, Osajima Y (1999) Inhibitory effect of $\alpha$-glucosidase inhibitors varies according to its origin. J Agric Food Chem 47:550-553
Oshima G, Shimabukuro H, Nagasawa K (1979) Peptide inhibitors of angiotensin I-converting enzyme in digests of gelatin by bacterial collagenase. Biochim Biophys Acta 566:128-137

Pihlanto L (2000) Bioactive peptides derived from bovine whey proteins: opioid and ACE inhibitory peptides. Trends Food Sci Technol 11:347-356

Pokora M, Zambrowicz A, Dạbrowska A, Eckert E, Setner B, Szołtysik M, Szewczuk Z, Zabłocka A, Polanowski A, Trziszka T, Chrzanowska J (2014) An attractive way of egg white protein by-product use for producing of novel anti-hypertensive peptides. Food Chem 151:500-505

Psallas M, Manes C (2012) Incretins in type 2 diabetes mellitus: cardiovascular and anti-atherogenic effects beyond glucose lowering. Hippokratia 16:100-105

Ramos-Nino ME, MacLean CD, Littenberg B (2008) Association of angiotensin-converting enzyme inhibitor therapy and comorbidity in diabetes: results from the Vermont diabetes information system. Endocr Disord 8:1-6

Saiga A, Okumura T, Makihara T, Katsuda SI, Miorimatsu F, Nishimura T (2006) Action mechanism of an angiotensin-Iconverting enzyme inhibitory peptide derived from chicken breast muscle. J Agric Food Chem 54:942-945

Schmidt SL, Hickey MS (2009) Regulation of insulin action by diet and exercise. J Equine Vet Sci 29:274-284

Silveira ST, Martínez-Maqueda D, Recio I, Hernández-Ledesma B (2013) Dipeptidyl peptidase-IV inhibitory peptides generated by tryptic hydrolysis of a whey protein concentrate rich in $\beta$-lactoglobulin. Food Chem 141:1072-1077

Skeggs LT, Kahn JR, Shumway NP (1956) The purification of hypertensin II. J Exp Med 103:301-307

Song JC, White CM (2002) Clinical pharmacokinetics and selective pharmacodynamics of new angiotensin converting enzyme inhibitors: an update. Clin Pharmacokinet 41:207-224

Spellman D, McEvoy E, O'Cuinn G, FitzGerald RJ (2003) Proteinase and exopeptidase hydrolysis of whey protein: comparison of the TNBS, OPA and $\mathrm{pH}$ stat methods for quantification of degree of hydrolysis. Int Dairy J 13:447-453

Tulipano G, Sibilia V, Caroli AM, Cocchi D (2011) Whey proteins as source of dipeptidyl peptidase IV (dipeptidyl peptidase-4) inhibitors. Peptides 32:835-838

Yu Z, Yin Y, Zhao W, Yu Y, Liu B, Liu J, Chen F (2011) Novel peptides derived from egg white protein inhibiting alphaglucosidase. Food Chem 129:1376-1382

Zambrowicz A, Timmer M, Polanowski A, Lubec G, Trziszka T (2013) Manufacturing of peptides exhibiting biological activity. Amino Acids 44:315-320 